\title{
ANALIZA POJĘĆ „REKLAMA” I „PROMOCJA” GIER HAZARDOWYCH“
}

I. Ustawa z 19 listopada 2009 r. o grach hazardowych ${ }^{1}$, która na nowo określiła warunki urządzania i zasady prowadzenia działalności w zakresie gier losowych, zakładów wzajemnych i gier na automatach, zaczęła obowiązywać 1 stycznia 2010 r. Co do faktu, że nowa ustawa była potrzebna, nikt nie miał wattpliwości, tym bardziej że zmieniający się rynek gier i zakładów wzajemnych pozostawił daleko w tyle ustawę z 29 lipca 1992 r. o grach i zakładach wzajemnych ${ }^{2}$. Oczekiwano ustawy kompleksowo regulującej rynek hazardu, która uwzględniałaby prawodawstwo unijne i orzecznictwa polskich sądów. Niewątpliwie potrzeba zmian była też spowodowana dynamicznie rozwijającym się rynkiem gier i zakładów wzajemnych, nowymi technologiami stosowanymi w tym sektorze gospodarki narodowej oraz występującymi nieprawidłowościami ${ }^{3}$.

Do systemowych zmian wprowadzonych tą ustawa, zwiększających ochronę społeczeństwa i praworządności przed negatywnymi skutkami hazardu, należy zaliczyć ograniczenia prowadzenia reklamy i promocji gier cylindrycznych, gier w karty, gier w kości, zakładów wzajemnych oraz gier na automatach, a także informowania o sponsorowaniu przez podmioty prowadzace działalność w zakresie tych gier ${ }^{4}$. Przyjmuje się, że takie ograniczenia, sa prawnym instrumentem polityki publicznej, który chroni gracza przed uzależnieniem. W doktrynie wskazuje się na ich podobieństwo do ograniczeń reklamy tzw. produktów sensytywnych, jak wyroby tytoniowe, napoje alkoholowe, produkty farmaceutyczne, których przyjmowanie może również wiązać się z ryzykiem uzależnienia ${ }^{5}$.

\footnotetext{
* Artykuł jest efektem badań naukowych prowadzonych w ramach projektu: „Reglamentacja obszaru hazardu w krajowym porządku prawnym na tle prawodawstwa Unii Europejskiej dotyczącego swobody przedsiębiorczości i swobody świadczenia usług”. Projekt dofinansowany ze środków Ministerstwa Nauki i Szkolnictwa Wyższego na utrzymanie potencjału badawczego Wydziału Administracji i Nauk Społecznych Wyższej Szkoły Informatyki i Zarządzania z siedzibą w Rzeszowie.

${ }^{1}$ Dz. U. 2009, Nr 201, poz. 1540 ze zm. (dalej jako: u.g.h.).

${ }^{2}$ T.jedn.: Dz. U. 2015, poz. 612 ze zm. (dalej jako: u.g.z.).

${ }^{3}$ Uzasadnienie rządowego projektu ustawy o grach hazardowych, druk sejmowy $\mathrm{nr} 2481$, Warszawa 2009, s. 1.

${ }^{4}$ Dla precyzji wywodów należy dodać, że z ograniczeń prowadzenia reklamy wyłączone sa następujące gry hazardowe: gry liczbowe, gry bingo i telebigno oraz loterie. Wyłączenie zawarte jest także w art. 29 ust. 5 u.g.h.

${ }^{5}$ E. Traple (red.), Prawo reklamy i promocji, Warszawa 2007, s. 178. Przy czym z badań wynika także, że problemy zdrowotne spowodowane uprawianiem hazardu nie poddaja się prostej analogii z innymi uzależnieniami. Hazard bowiem tym różni się od alkoholu czy narkotyków, że jest
} 
Efektem wprowadzenia tej regulacji do u.g.h. była penalizacja w przepisach karnych skarbowych zakazanych form zachęcania do udziału w określonych grach hazardowych oraz reklamy nazwy (firmy) podmiotu organizujacego hazard (art. 103 pkt 9 u.g.h. wprowadził zmianę przez dodanie art. 110a do ustawy z 10 września 1999 r. - Kodeks karny skarbowy) ${ }^{6}$.

Podjęte przez ustawodawcę działania w zakresie uregulowania obszaru hazardu, w tym w zakresie ograniczeń w urządzaniu gier hazardowych, wiązało się z jednoczesnym zdefiniowaniem pojęć reklamy, promocji i informowania o sponsorowaniu w art. 29 u.g.h.

Celem niniejszych rozważań obok oczywistych aspektów poznawczych jest gruntowne badanie pojęć „reklama” i „promocja” w odniesieniu do gier cylindrycznych, gier w karty, gier w kości, zakładów wzajemnych oraz gier na automatach. Dodatkowo analizie poddano pojęcie „informowanie o sponsorowaniu”, gdyż jest bezpośrednio związane z przedmiotem opracowania. Zasadnicze pytanie, na jakie autor chce odpowiedzieć, brzmi: Czy przyjęte w u.g.h. definicje tych pojęć nie budzą wątpliwości interpretacyjnych? Rozstrzygnięcie tego problemu badawczego należy przy tym powiązać z odpowiedzią na pytanie pomocnicze, czy użyte w tych definicjach sformułowania są wystarczająco precyzyjne, czy należy je zastapić innymi słowami lub uzupełnić o dodatkowe zwroty.

II. Reklama stanowi przedmiot zainteresowania różnych dziedzin nauki w tym prawa, ekonomii i socjologii. Definicje reklamy formułowane dla potrzeb konkretnych badań różnią się od siebie. Z reguły proponuje się dwa ujęcia reklamy, tj. szersze, czyli wszelkie działania propodażowe, i węższe, tj. „zaplanowane komunikowanie (czy też proces komunikacji społecznej) mające na celu ekonomicznie skuteczną informację, perswazję oraz sterowanie decyzjami ${ }^{7}$.

Europejska konwencja o telewizji ponadgranicznej ${ }^{8} \mathrm{w}$ art. 2 lit. f stanowi, że reklama to każdy publiczny przekaz nadawany za opłatą lub inną formą wynagrodzenia albo w celach autopromocji, zmierzajacy do promowania sprzedaży, zakupu lub wynajmu produktu lub usługi, promocji idei lub sprawy, albo osiagnięcia innego efektu pożądanego przez reklamodawcę lub samego nadawcę. Natomiast sponsorowanie, zgodnie z art. 2 pkt g ww. Konwencji, oznacza udział osoby fizycznej lub prawnej, niezaangażowanej w działalność

czymś niematerialnym, zatem nie oddziałuje na organizm w tak łatwy do przewidzenia sposób, jak środki chemiczne. W procesie powstawania uzależnienia mamy do czynienia ze złożoną interakcją czynników poznawczych, społecznych, motywacyjnych i biologicznych, które - co należy dodać - najlepiej badać, obserwujac rzeczywiste zachowania graczy w miejscach uprawiania hazardu (M. Dickerson, E. Baron, Contemporary issues and future directions for research in pathological gambling, „Addiction” 95, 2000, s. 1145-1159, za: B. Dzik, Hazard, w: T. Tyszka (red.), Psychologia ekonomiczna, Gdańsk 2004, s. 575.

6 T.jedn.: Dz. U. 2013, poz. 186 ze zm. (dalej jako: k.k.s.).

7 J. Preussner-Zamorska, Aksjologiczne uwarunkowania reklamy, „Zeszyty Naukowe Uniwersytetu Jagiellońskiego" 1993, z. 62, s. 55-68; eadem, Uwagi na temat zakazu reklamowania wolnych zawodów, „Rejent” 1994, nr 3, s. 14-32.

8 Europejska konwencja o telewizji ponadgranicznej sporządzona w Strasburgu dnia 5 maja 1989 r. ratyfikowana przez Polskę w dniu 9 lipca 1990 r., Dz. U. 1995, Nr 32, poz. 160 ze zm. (dalej jako: Konwencja). 
transmisyjną ani w produkcję dzieł audiowizualnych, w bezpośrednim lub pośrednim finansowaniu programu w celu promocji jej nazwy, znaku fabrycznego lub wizerunku. Warto jednak dodać, że z pojęcia reklamy wyłącza się ogłoszenia wytworzone przez nadawcę w związku z jego własnymi programami i inne produkty bezpośrednio związane $\mathrm{z}$ realizacją celów tych programów oraz ogłoszenia $\mathrm{w}$ interesie publicznym i apele o charakterze dobroczynnym rozpowszechniane bezpłatnie.

W ustawodawstwie polskim można znaleźć definicje reklamy, promocji oraz informowania o sponsorowaniu. Zgodnie z art. $2^{1}$ ust. 1 pkt 3 ustawy z 26 października 1982 r. o wychowaniu w trzeźwości i przeciwdziałaniu alkoholizmowi ${ }^{9}$ reklama napojów alkoholowych to publiczne rozpowszechnianie znaków towarowych napojów alkoholowych lub symboli graficznych z nimi związanych, a także nazw i symboli graficznych przedsiębiorców produkujących napoje alkoholowe, nieróżniących się od nazw i symboli graficznych napojów alkoholowych, służące popularyzowaniu znaków towarowych napojów alkoholowych. Przy czym za reklamę nie uważa się informacji używanych do celów handlowych pomiędzy przedsiębiorcami zajmującymi się produkcja, obrotem hurtowym i handlem napojami alkoholowymi. Natomiast promocja napojów alkoholowych to publiczna degustacja napojów alkoholowych, rozdawanie rekwizytów związanych z napojami alkoholowymi, organizowanie premiowanej sprzedaży napojów alkoholowych, a także inne formy publicznego zachęcania do nabywania napojów alkoholowych (art. $2^{1}$ ust. 1 pkt 2 ustawy). W końcu informowanie o sponsorowaniu to prezentowanie informacji zawierajacej nazwę sponsora lub jego znak towarowy w związku ze sponsorowaniem (art. $2^{1}$ ust. 1 pkt 5 ustawy).

Zgodnie z definicją zawartą w art. 4 pkt 17 ustawy z 29 grudnia 1992 r. o radiofonii i telewizji ${ }^{10}$, reklama jest przekaz handlowy, pochodzacy od podmiotu publicznego lub prywatnego, w związku z jego działalnością gospodarcza lub zawodowa, zmierzający do promocji sprzedaży lub odpłatnego korzystania z towarów lub usług. Nadto reklamą jest także autopromocja. W rozumieniu ustawy autopromocją jest każdy przekaz pochodzacy od dostawcy usługi medialnej majacy służyć bezpośrednio lub pośrednio promocji jego audycji, towarów lub usług. Natomiast zgodnie z art. 4 pkt 18 tej ustawy sponsorowaniem jest każdy wkład w finansowanie usługi medialnej lub audycji przez podmiot, który nie dostarcza usług medialnych i nie produkuje audycji, w celu promocji jego nazwy, firmy, renomy, działalności, towaru lub usługi, znaku towarowego lub innego oznaczenia indywidualizujacego.

Kolejną definicję reklamy podaje ustawa z 9 listopada 1995 r. o ochronie zdrowia przed następstwami używania tytoniu i wyrobów tytoniowych ${ }^{11}$. Zgodnie z definicją zawartą w art. 2 pkt 5 tej ustawy reklama wyrobów tytoniowych to rozpowszechnianie komunikatów, wizerunków marek wyrobów tytoniowych lub symboli z nimi związanych, a także nazw i symboli graficznych firm produkujących wyroby tytoniowe, nieróżniące się od nazw i symboli graficznych wyrobów tytoniowych, służących popularyzowaniu marek

9 T.jedn.: Dz. U. 2012, poz. 1356 ze zm.

10 T.jedn.: Dz. U. 2011, Nr 43, poz. 226 ze zm.

11 Dz. U. 1996, Nr 10, poz. 55 ze zm. 
wyrobów tytoniowych. Za reklamę nie uważa się informacji używanych do celów handlowych pomiędzy firmami zajmującymi się produkcja, dystrybucją i handlem wyrobami tytoniowymi. Tymczasem informacja o wyrobach tytoniowych to ,informacja o markach wyrobów tytoniowych oraz o zawartości substancji szkodliwych, niezawierająca przekazu zachęcającego do zakupu lub używania wyrobów tytoniowych, umieszczona wyłącznie w punktach sprzedaży tych wyrobów” (art. 2 pkt 6 ustawy). Natomiast promocja wyrobów tytoniowych to „publiczne rozdawanie wyrobów tytoniowych lub rekwizytów tytoniowych, organizowanie degustacji, premiowanej sprzedaży wyrobów tytoniowych, oferowanie wyrobów tytoniowych konsumentom po obniżonej cenie w stosunku do ceny wydrukowanej na opakowaniu jednostkowym wyrobu, organizowanie konkursów opartych na zakupie wyrobów lub rekwizytów tytoniowych oraz inne formy publicznego zachęcania do nabywania lub używania wyrobów tytoniowych, bez względu na formę dotarcia do adresata" (art. 2 pkt 7 ustawy).

Niezwykle starannie podszedł ustawodawca do kwestii reklamy w ustawie z 6 września 2001 r. - Prawo farmaceutyczne, formułując odrębny rozdział dotyczący reklamy produktów leczniczych ${ }^{12}$. Przepisy ustawy stanowia, że reklama produktu leczniczego jest działalność polegająca na informowaniu lub zachęcaniu do stosowania produktu leczniczego, majacca na celu zwiększenie liczby przepisywanych recept, dostarczania, sprzedaży lub konsumpcji produktów leczniczych. Jednocześnie ustawa określa, co nie stanowi reklamy produktów leczniczych, np. informacje umieszczone na opakowaniach oraz załączonych do opakowań produktów leczniczych, zgodnych z pozwoleniem na dopuszczenie do obrotu, czy też korespondencja, której towarzyszą materiały informacyjne o charakterze niepromocyjnym niezbędne do udzielenia odpowiedzi na pytania dotyczące konkretnego produktu leczniczego, w tym produktu leczniczego dopuszczonego do obrotu bez konieczności uzyskania pozwolenia.

Interesujące jest rozumienie pojęcia „reklama” przedstawione przez Bogumiła Brzezińskiego i Marka Kalinowskiego ${ }^{13}$. Autorzy uznają za reklamę działania, których celem jest kształtowanie popytu przez poszerzenie wiedzy przyszłych nabywców o towarach bądź usługach, ich cechach i przeznaczeniu w celu zachęcenia ich do nabywania towarów bądź usług od tego właśnie, a nie innego podmiotu gospodarczego. Technicznym sposobem reklamy może być ogłoszenie prasowe, radiowe lub telewizyjne, a także plakat czy afisz stały, a ponadto rozsyłanie folderów i innych informacji handlowych nabywcom. Oczywiste jest, że technicznym sposobem reklamy może być także informacja w Internecie.

Należy również zwrócić uwagę na wyrok NSA z 8 kwietnia 1997 r., w którym Sąd w konkretnej sprawie uznał, że celem reklamy jest pozyskiwanie nowych kontrahentów i członków ${ }^{14}$.

12 T.jedn.: Dz. U. 2008, Nr 45, poz. 271 ze zm.

13 B. Brzeziński, M. Kalinowski, Komentarz do podatku dochodowego od osób prawnych, Warszawa 1996, s. 143-144.

14 Wyrok NSA z 8 kwietnia 1997 r., SA/KA 2976/95, Lex, nr 28718. 
III. Odnosząc się do kwestii związanych z reklama, warto zwrócić uwagę, że reklama może być sprzeczna z interesem konsumenta (gracza), np. wskutek przekazywania nierzetelnych informacji na temat usługi (gry) ${ }^{15}$. Dlatego ustawodawca wprowadził regulacje wyznaczające ramy prawne działalności reklamowej ustawa z 16 kwietnia 1993 r. o zwalczaniu nieuczciwej konkurencji ${ }^{16}$. Zgodnie z art. 3 ust. 1 tej ustawy czynem nieuczciwej konkurencji jest działanie sprzeczne z prawem lub dobrymi obyczajami ${ }^{17}$, o ile zagraża ono lub narusza interes innego przedsiębiorcy lub klienta (klauzula generalna). Sąd Najwyższy w jednym z orzeczeń stwierdził, że do uznania konkretnego działania (reklamy) za czyn nieuczciwej konkurencji nie wystarczy stwierdzenie, iż jest on sprzeczny z dobrymi obyczajami, lecz musi wystapić także naruszenie interesu innego przedsiębiorcy lub klienta ${ }^{18}$.

W u.z.n.k. regulacją o dużym znaczeniu dla działalności reklamowej jest także art. 16, który obejmuje katalog rodzajów reklam uznawanych za czyny nieuczciwej konkurencji (nie jest to katalog zamknięty). W świetle tej regulacji prawnej czynem nieuczciwej konkurencji w zakresie reklamy jest w szczególności reklama sprzeczna z przepisami prawa, dobrymi obyczajami lub uchybiająca godności człowieka, reklama wprowadzająca klienta w błąd i mogąca przez to wpłynać na jego decyzję co do nabycia towaru lub usługi, reklama odwołująca się do uczuć klientów przez wywoływanie lęku, wykorzystywanie przesądów lub łatwowierności dzieci, wypowiedź, która zachęcając do nabywania towarów lub usług, sprawia wrażenie neutralnej informacji, reklama, która stanowi istotną ingerencję w sferę prywatności, w szczególności przez uciążliwe dla klientów nagabywanie w miejscach publicznych, przesyłanie na koszt klienta niezamówionych towarów lub nadużywanie technicznych środków przekazu informacji ${ }^{19}$.

Przy ocenie reklamy wprowadzającej w błąd należy uwzględnić wszystkie jej elementy, zwłaszcza dotyczące ilości, jakości, składników, sposobu wykonania, przydatności, możliwości zastosowania, naprawy lub konserwacji reklamowanych towarów lub usług, a także zachowania się klienta. Ustawa o zwalczaniu nieuczciwej konkurencji posługuje się także pojęciem reklamy porównawczej, czyli umożliwiającej bezpośrednio lub pośrednio rozpoznanie konkurenta albo towarów lub usług oferowanych przez konkurenta. Z uwagi na to, że reklama zawierajacca nierzetelna informację szkodzi przede wszystkim konsumentom, a dopiero później przedsiębiorcom, dla lepszej ochrony konsumentów u.z.n.k. ustanowiła szeroki krąg podmiotów odpowiedzialnych za nieuczciwą reklamę ${ }^{20}$. Dlatego zgodnie z art. 17 u.z.n.k. odpowiedzialność spoczywa także na agencji

${ }^{15}$ K. Grzybczyk, Prawo reklamy, Kraków 2004, s. 48.

16 T.jedn.: Dz. U. 2003, Nr 153, poz. 1503 ze zm. (dalej jako: u.z.n.k.).

${ }^{17} \mathrm{Z}$ reguły za sprzeczne $\mathrm{z}$ dobrymi obyczajami w rozumieniu u.z.n.k. należy uznać czyny zakazane przez kodeksy etyki zawodowej. Przy czym należy zaznaczyć, że pojęcie „dobre obyczaje” użyte w u.z.n.k. nie jest łatwe do odkodowania, gdyż nie można go wiązać ze zwrotem „zasady współżycia społecznego" (T. M. Knypl, Zwalczanie nieuczciwej konkurencji w Polsce i w Europie, Sopot 1994, s. 38).

${ }^{18}$ Wyrok SN z 26 września 2002 r., III CKN 213/01.

${ }^{19}$ E. Nowińska, Zwalczanie nieuczciwej reklamy. Zagadnienia cywilno-prawne, Kraków 1998, s. 70 i n.

${ }^{20}$ K. Grzybczyk, op. cit., s. 73-74. 
reklamowej albo innym przedsiębiorcy, który reklamę opracował. Popełnienie czynu nieuczciwej konkurencji, w tym również reklamy, rodzi odpowiedzialność cywilną oraz odpowiedzialność za wykroczenie.

IV. Warto przypomnieć, że definicja reklamy wyrażona była również w art. 8 uchylonej u.g.z. W świetle tej definicji przez reklamę rozumiało się zachęcanie do udziału w grach i zakładach wzajemnych, przekonywanie o ich zaletach, informowanie o miejscach, w których są urządzane, i możliwościach uczestnictwa. Zabronione było reklamowanie na terytorium Rzeczypospolitej Polskiej: wideoloterii, gier cylindrycznych, gier w karty, gier w kości, zakładów wzajemnych, gier na automatach oraz gier na automatach o niskich wygranych. Naruszenie zakazu oznaczało odpowiedzialność karna skarbowa z art. $107 \S 1$ k.k.s. Mimo tego zakazu reklamy internetowych firm bukmacherskich można było znaleźć na koszulkach sportowców, w gazetach sportowych i oczywiście w sieci Internet. Takie sytuacje wynikały z rozpowszechnionej opinii, że polskie ustawodawstwo jest w tym zakresie niespójne z prawodawstwem unijnym. Dowodem na to miało być zestawienie teorii, tj. zakaz reklamy hazardu, z praktyka polegająca m.in. na tym, że polscy widzowie mogą te same reklamy oglądać na stadionach, np. gdy reprezentacja gra za granica.

Niezwykle istotne w świetle prowadzonych rozważań sa aktualne definicje zawarte w art. 29 u.g.h., które precyzuja, co ustawa hazardowa rozumie przez pojęcie reklamy, promocji i informowania o sponsorowaniu.

W świetle tego unormowania reklama jest publiczne (a zatem dostępne dla wszystkich) rozpowszechnianie znaków towarowych lub symboli graficznych i innych oznaczeń z nimi związanych, a także nazw i symboli graficznych podmiotów prowadzacych działalność w zakresie gier cylindrycznych, gier w karty, gier w kości, zakładów wzajemnych lub gier na automatach oraz informacji o miejscach, w których takie gry lub zakłady są urządzane, i możliwościach uczestnictwa (art. 29 ust. 6 u.g.h.). Natomiast przez promocję tych gier hazardowych rozumie się w świetle ustawy ich publiczną prezentację, rozdawanie rekwizytów z nimi związanych, wręczanie żetonów lub dowodów uczestnictwa $\mathrm{w}$ tych grach albo ich sprzedaż w miejscach publicznych, a także inne formy publicznego zachęcania do uczestnictwa w nich lub przekonywania o ich zaletach bądź zachęcania do wstępu do kasyn gry lub punktów przyjmowania zakładów wzajemnych (art. 29 ust. 7 u.g.h.). Za reklamę i promocję ww. gier lub zakładów wzajemnych uważa się również reklamę i promocję produktów i usług, których nazwa, znak towarowy, kształt graficzny lub opakowanie wykorzystuje podobieństwo lub jest tożsame z oznaczeniem gier cylindrycznych, gier w karty, gier w kości, zakładów wzajemnych albo z firma, nazwa lub oznaczeniem podmiotu prowadzącego działalność w zakresie gier lub zakładów wzajemnych (art. 29 ust. 8 u.g.h.). W końcu za reklamę i promocję wskazanych wcześniej gier hazardowych uważa się również reklamę i promocję podmiotów, których wizerunek reklamowy wykorzystuje podobieństwo lub jest tożsamy z oznaczeniem tych gier lub zakładów wzajemnych, kasyna gry lub punktu przyjmowania zakładów wzajemnych albo z firma, nazwą lub 
oznaczeniem podmiotu prowadzącego działalność w zakresie tych gier lub zakładów wzajemnych, lub innym symbolem obiektywnie odnoszącym się do takich oznaczeń (art. 29 ust. 9 u.g.h.).

Przez sponsorowanie przepis art. 29 ust. 10 u.g.h. uznaje bezpośrednie lub pośrednie finansowanie lub współfinansowanie działalności osób fizycznych, osób prawnych lub jednostek organizacyjnych niemających osobowości prawnej, w celu upowszechniania, utrwalania lub podniesienia renomy gier cylindrycznych, gier w karty, gier w kości, zakładów wzajemnych oraz gier na automatach, podmiotów prowadzących działalność w tym zakresie lub innego oznaczenia indywidualizującego podmiot prowadzący działalność w zakresie przedstawionych gier hazardowych lub jego działalność, w zamian za informowanie o sponsorowaniu.

W końcu przez informowanie o sponsorowaniu art. 29 ust. 11 u.g.h. rozumie prezentowanie informacji zawierającej nazwę lub innego oznaczenia indywidualizującego sponsora w związku ze sponsorowaniem.

Powyższa prezentacja art. 29 u.g.h. wskazuje, że ustawodawca w sposób niezwykle szeroki ujął definicje przedstawionych pojęć, co może być częściowo usprawiedliwione doświadczeniami z funkcjonowania poprzedniej, ogólnej definicji reklamy. Obok bowiem takich zdarzeń, jak publiczne rozpowszechnianie znaków towarowych lub symboli graficznych i innych oznaczeń, a także nazw i symboli graficznych podmiotów prowadzących działalność w zakresie ww. gier hazardowych, przez reklamę i promocję rozumie się także reklamę i promocję produktów i usług, których nazwa, znak towarowy, kształt graficzny, lub opakowanie, wykorzystuje podobieństwo lub jest tożsame $\mathrm{z}$ oznaczeniem tych gier lub zakładów wzajemnych ${ }^{21}$. W ten sposób ustawodawca zapobiega obchodzeniu zakazów reklamy i promocji hazardu przez wykorzystanie podobieństwa nazw, znaków, kształtu czy wizerunków reklamowych. Oznacza to, że przykładowo pojawiające się dawniej na różnych festynach bądź innych imprezach podmioty proponujące rozrywkę w postaci gry nie na pieniądze na urządzeniu, którego nie nazywają ruletka, ale które jest identyczne i działa jak ruletka, sa objęte ustawowym ograniczeniem i nie mogą funkcjonować w tym obszarze.

Zgodzić się trzeba, że w aspekcie ochrony gracza i społeczeństwa przed negatywnymi skutkami hazardu takie podejście do reklamy gier lub zakładów jest racjonalne. Przecież organizowanie rozrywki łudząco przypominającej np. ruletkę zawiera w sobie niewątpliwie aspekt szkoleniowy, gdyż pozwala zapoznać się z zasadami gry i mechanizmem działania urządzenia. Natomiast jednym z czynników, który sprawia, że ludzie nie chodza powszechnie do kasyn, jest brak wiedzy o funkcjonujących tam zasadach. Potencjalny gracz obawia się nie tylko przegranej, ale też tego, że nie będzie wiedział, jak się ma zachować. Jest to typowa ludzka reakcja przy korzystaniu z czegoś nowego. Osoby wyedukowane na urządzeniach imitujących prawdziwe mogą stracić te obawy, co w sumie może przyczynić się do zwiększenia uzależnienia od gry.

${ }^{21}$ Profesor Leszek Wilk za absolutnie niedopuszczalne uznaje rozwiązanie polegające na rozszerzeniu zakazów reklamy na produkty, których m.in. nazwy wykorzystują podobieństwo z oznaczeniami gier: L. Wilk, Hazard. Studium kryminologiczne i prawne, Warszawa 2012, s. 137. 
V.W tym miejscu należy zrobić uwagę, że definicja przyjęta w art. 29 u.g.h., co zauważyła już doktryna, wykracza poza obręb znanych definicji reklamy, przede wszystkim dlatego, że odcina się do celowościowego (podmiotowego) sensu reklamy, czyli zachęcania do kupowania (grania) ${ }^{22}$. Jak wskazują bowiem wcześniej przytoczone poglądy doktryny, za reklamę uznaje się, mówiąc ogólnie, kształtowanie popytu przez poszerzenie wiedzy przyszłych nabywców o towarach bądź usługach, ich cechach i przeznaczeniu ${ }^{23}$. W przytoczonym wcześniej orzeczeniu NSA znajdujemy stwierdzenie, że celem reklamy jest pozyskiwanie nowych kontrahentów i członków. Także Europejska konwencja o telewizji ponadgranicznej stanowi, że reklama to każdy publiczny przekaz nadawany w celach autopromocji, zmierzajacy do promowania sprzedaży, zakupu, wynajmu produktu lub usługi, promocji idei lub sprawy. Ten cel pozwala odróżnić reklamę od ogłoszenia, które ma charakter czysto informacyjny. Wskazane w ustawie hazardowej elementy reklamy, tj. publiczne rozpowszechnianie znaków towarowych lub symboli graficznych i innych oznaczeń z nimi związanych gier cylindrycznych, gier w karty, gier w kości, zakładów wzajemnych lub gier na automatach, a także nazw i symboli graficznych podmiotów, które je prowadza, maja charakter przedmiotowy. Wydaje się, że pełna definicja reklamy, a zatem zgodna z ogólnym pojęciem reklamy powinna zawierać zarówno elementy przedmiotowe, jak i podmiotowe. Istotne powinny być takie zwroty w definicji reklamy, stanowiące elementy podmiotowe, jak: „popularyzowanie znaków towarowych i symboli graficznych” lub też, jak było to ujęte w art. 8 uchylonej u.g.z., ,zachęcanie do udziału” czy „przekonywanie o ich zaletach". Wtedy możemy powiedzieć, że reklama, która zachęca do udziału w ww. grach hazardowych, ma typowy dla reklamy charakter celowościowy, zawiera element wywierający wpływ na wolę określonych ludzi. Jest to tym bardziej ważne, że przecież podobnie jak w przypadku „produktów sensytywnych", u podstawy wprowadzenia ograniczeń w reklamie i promocji hazardu leży cel polegający na ochronie zdrowia ${ }^{24}$.

Warto przypomnieć, że wcześniej powołane definicje reklamy, w tym w ustawie o wychowaniu w trzeźwości i przeciwdziałaniu alkoholizmowi czy w ustawie o ochronie zdrowia przed następstwami używania tytoniu i wyrobów tytoniowych, zawierały elementy przedmiotowe, niekiedy bardzo zbliżone do zwrotów użytych w definicji u.g.h. Przykładowo reklama napojów alkoholowych to publiczne rozpowszechnianie znaków towarowych napojów alkoholowych lub symboli graficznych z nimi związanych, co brzmi bardzo podobnie do reklamy gier lub zakładów. Jednak obok zbliżonych elementów przedmiotowych w definicjach reklamy opisanych w ww. ustawach pojawiają się także elementy podmiotowe, np. że reklama służy popularyzowaniu znaków towarowych napojów alkoholowych". Do tego np. ustawa o wychowaniu w trzeźwości i przeciwdziałaniu alkoholizmowi precyzuje, że za reklamę nie uważa się informacji używanych do celów handlowych pomiędzy przedsiębiorcami zajmującymi się produkcja, obrotem hurtowym i handlem napojami alkoholowy-

22 L. Wilk, op. cit., s. 134-135.

23 B. Brzeziński, M. Kalinowski, op. cit., s. 143-144.

24 E. Traple (red.), op. cit., s. 180. 
mi. Podobnie sprawę traktuje ustawa o ochronie zdrowia przed następstwami używania tytoniu i wyrobów tytoniowych. Elementy podmiotowe w u.g.h. odnajdujemy, tyle że nie przy definicji reklamy, a promocji, którą są formy publicznego zachęcania do uczestnictwa lub przekonywania o zaletach gier lub zakładów wzajemnych bądź zachęcania do wstępu do kasyn gry lub punktów przyjmowania zakładów wzajemnych. Jest to definicja zgodna z pojęciem promocji opisanym w ustawie o wychowaniu w trzeźwości i przeciwdziałaniu alkoholizmowi oraz zbliżona w swej treści do znaczenia słownikowego ${ }^{25}$.

Efekt końcowy funkcjonowania aktualnej definicji reklamy gier cylindrycznych, gier w karty, gier w kości, zakładów wzajemnych lub gier na automatach jest taki, że adresaci zakazów mogą mieć bardzo duże problemy z ustaleniem, czy ich zachowanie stanowi naruszenie normy prawnofinansowej, co zarazem może skutkować odpowiedzialnością karną skarbową. Z drugiej strony organy ścigania, trzymając się ściśle definicji, mogą reagować na każdy przejaw realizacji definicji reklamy, co może spotkać się z negatywną reakcja ze strony społeczeństwa, ale i wymiaru sprawiedliwości. Jest to efekt stworzenia definicji reklamy na bazie elementów przedmiotowych, z całkowitym wyzuciem elementów podmiotowych, co zakłóca standardowe rozumienie reklamy. W zwiąku z tym, że nawet sama graficzna prezentacja zwiazzana z grami może być uznana za naruszenie zakazu reklamy hazardu, właściwie trudno znaleźć w tym obszarze punkt bezpieczny. Jeżeli wychodząc na plażę, założymy koszulkę z obrazkiem przypominającym koło ruletki, to trzymając się definicji reklamy z ustawy hazardowej, niewątpliwie możemy być podejrzewani o publiczne rozpowszechnianie gry cylindrycznej. Dla uniknięcia takich kontrowersyjnych ocen wystarczy uzupełnić definicję reklamy o element podmiotowy, który zmuszałby organy ścigania o dodatkowe ustalenie, czy ta koszulka z nadrukiem, z uwagi na okoliczności, służy popularyzowaniu gier hazardowych, zachęca do udziału w ruletce, czy też jest zwykłym, przypadkowym elementem stroju plażowicza. Podobne zagrożenie pojawia się nawet w przypadku umieszczenia na kopercie logo firmy hazardowej. Przepisy ustawy prawo farmaceutyczne wykluczają takie zagrożenia, stanowiąc, że nie jest reklamą produktów leczniczych informacja umieszczona na opakowaniach czy korespondencja, której towarzyszą materiały informacyjne o charakterze niepromocyjnym niezbędne do udzielenia odpowiedzi na pytania dotyczące konkretnego produktu leczniczego.

VI. Inny problem, jaki pojawia się przy definicji reklamy i promocji, to stosowanie przez ustawodawcę nieostrych zwrotów. Przykładowo przepis art. 29 ust. 6 u.g.h. stanowi, że: „[...] przez reklamę gier [...] rozumie się publiczne rozpowszechnianie znaków towarowych lub symboli graficznych i innych oznaczeń z nimi związanych [...]". Natomiast art. 29 ust. 7 u.g.h. dotyczący definicji promocji stanowi, że: „[...] przez promocję gier [...] rozumie się publiczną prezentację tych gier lub zakładów, rozdawanie rekwizytów z nimi związanych [...]”.

${ }^{25}$ Promocja - to działanie zmierzające do zwiększenia popularności czegoś lub kogoś, lansowanie, protegowanie, upowszechnianie czegoś (Stownik wyrazów obcych, red. E. Sobol, Warszawa 1996, s. 906). 
Nie wiadomo jednak, jak rozumieć ten „związek”. Choć biorąc pod uwagę zakres pojęciowy definicji reklamy, można przyjąć, że „związkiem ${ }^{26}$ " może być w zasadzie wszystko, co w jakikolwiek sposób kojarzy się z danymi grami lub zakładami wzajemnymi ${ }^{27}$.

Kolejne zagrożenie wiąże się ze słowem „podobieństwo”. W definicji reklamy znajdujemy i takie sformułowanie, że za reklamę i promocję gier cylindrycznych, gier w karty, gier w kości, zakładów wzajemnych lub gier na automatach uważa się również reklamę i promocję produktów i usług, których nazwa, znak towarowy, kształt graficzny lub opakowanie wykorzystuja podobieństwo lub są tożsame z oznaczeniem tych gier i zakładów wzajemnych. Słowo „tożsamość” 28 jest w miarę precyzyjne, ale już w kwestii „podobieństwa” ${ }^{29}$ moga być problemy. W doktrynie funkcjonuje pogląd, że jest to słowo na tyle nieostre (w pewnym sensie potwierdza to definicja: taki sam lub prawie taki sam), że czyni praktycznie całkowicie nieczytelną granicę zakazu reklamy i promocji hazardu. W efekcie stwierdzenie zaistnienia „podobieństwa” wymagać może opinii biegłego. Przepisy zakazujące reklamy i promocji hazardu, z którymi wiąże się odpowiedzialność karna skarbowa, a zarazem które sa nieprecyzyjne, mogą być przy pewnych okolicznościach uznane za naruszające zasadę określoności czynu zabronionego ${ }^{30}$.

Problem istnieje także przy definicji informowania o sponsorowaniu ${ }^{31}$, w której czytamy o „prezentowaniu informacji”, ale brak jest słowa nadającego tej prezentacji powszechny, publiczny charakter. W efekcie nawet zabawa $\mathrm{w}$ głuchy telefon $\mathrm{z}$ podawanym sobie słowem indywidualizujacym sponsora powinna być uznana za zakazaną. Słowo to w encyklopedycznym tłumaczeniu oznacza: pokazywać, ukazywać, wystawiać na widok publiczny ${ }^{32}$. Można więc słowo „prezentacja” kojarzyć ze zdarzeniem publicznym, ale też z faktem osobistym, czysto prywatnym: prezentuję w domu przed rodziną informację zawierającą nazwę sponsora.

VII. Adresat zakazów dotyczących reklamy, promocji oraz informowania o sponsorowaniu jest zdefiniowany w art. 29 ust. 4 u.g.h. Jest to zatem osoba fizyczna, osoba prawna oraz jednostka organizacyjna niemająca osobowości prawnej, która zleca lub prowadzi czynności objęte zakazem, umieszcza rekla-

\footnotetext{
${ }^{26}$ Stownik 100 tysięcy potrzebnych stów, red. J. Bralczyk, Warszawa 2008, s. 1015 - wskazuje na wiele znaczeń słowa „związek”. Tu można przyjąć, że jest to stosunek między rzeczami, zjawiskami, połączonymi ze sobą w jakiś sposób.

${ }^{27}$ Taki zapis może rodzić problemy, gdyż ludzka wyobraźnia działa różnie i w zależności od tego dla jednych dany rekwizyt może wykazywać związek z grami, podczas gdy inni tego związku nie dostrzega.

${ }^{28}$ W. Boryś, Stownik etymologiczny języka polskiego, Kraków 2005, s. 639: „'tożsamy’ - ten sam lub taki sam, identyczny".

${ }^{29}$ Ibidem, s. 453: „podobny' - taki sam lub prawie taki sam, identyczny lub zbliżony pod jakimś względem".

${ }^{30}$ L. Wilk, op. cit., s. 137.

${ }^{31}$ Informowanie o sponsorowaniu to prezentowanie informacji zawierającej nazwę sponsora lub jego znak towarowy w związku ze sponsorowaniem.

${ }_{32}$ Mały stownik jezzyka polskiego, red. S. Skorupka, H. Auderska, Z. Łempicka, Warszawa 1993, s. 629 .
} 
mę lub informację albo czerpie korzyści z takich czynności. Zgodzić się trzeba z poglądami doktryny, że zakreślony w ten sposób adresat jest bardzo nieprecyzyjny ${ }^{33}$. Szczególne wątpliwości rodzą się na tle zakazu czerpania korzyści z zakazanej reklamy, promocji i informowania o sponsorowaniu. Korzyści może bowiem czerpać urządzający i prowadzący gry cylindryczne, gry w karty, gry w kości, zakłady wzajemne lub gry na automatach, wszystkie osoby zajmujące się reklamą w tym także właściciel nieruchomości, na której znajduje się odpłatna reklama, jak również osoba, która zobaczyła reklamę, ponieważ np. wygrała nagrodę. Biorąc pod uwagę, że funkcjonujący w ustawie hazardowej zakaz czerpania korzyści jest naruszeniem penalizowanym przez art. 110a $\S 2$ k.k.s., racjonalne byłoby wskazanie jednoznacznie, kto może być podmiotem tego przestępstwa skarbowego (wykroczenia w przypadku mniejszej wagi - art. 110a $§ 3$ k.k.s.). Przy czym tak ogólne stwierdzenie, jak „czerpanie korzyści”, zmusza do badania każdej osoby zaangażowanej w ten proceder, często niemajaccej pojęcia o charakterze reklamy i związanej z tym odpowiedzialności. Nie ma wątpliwości, że odpowiedzialność karna skarbowa w przypadku art. 110a $§ 2$ k.k.s. może mieć miejsce tylko wtedy, gdy wykażemy zamiar popełnienia czynu zabronionego. Trudno zarazem co do zasady zrównać świadomość organizatora gier i właściciela przydrożnej działki, na której stoi tablica reklamowa. Jeszcze trudniej mówić o świadomości osoby, która w następstwie przeczytania reklamy, zachęcona ogłoszeniem, zagrała i w następstwie tego wygrała. Do stwierdzenia naruszenia zakazu i przypisania odpowiedzialności potrzebne jest wykazanie, że osoba świadomie czerpała korzyści z reklamy lub promocji omawianych gier i zakładów wzajemnych, a także czym była ta korzyść oraz jaka była jej wartość. Ustalenie całego kręgu adresatów i zebranie przekonujących dowodów może okazać się trudne. Zatem łatwiejsze wydaje się udowodnienie zlecenia prowadzonej zakazanej reklamy lub promocji ${ }^{34}$.

VIII. Przedstawione rozważania odnosiły się do istotnych problemów, wynikających z analizy pojęć reklama, promocja i informowanie o sponsorowaniu, przy czym zmierzały one bezpośrednio do udzielenia odpowiedzi na kluczowe pytanie: Czy obowiązujące w prawie polskim definicje powyższych pojęć nie budzą wątpliwości interpretacyjnych? Dodatkowo ten problem badawczy powiązano $\mathrm{z}$ odpowiedzią na pytanie, czy użyte $\mathrm{w}$ definicjach sformułowania są wystarczająco precyzyjne, czy należy je zastapić innymi słowami lub uzupełnić o dodatkowe zwroty. Przy tak sformułowanym założeniu opracowania w pierwszej kolejności zwrócono uwagę na stosowane zarówno w aktach prawnych, orzecznictwie, jak i doktrynie pojęcia reklamy, promocji i informowania o sponsorowaniu. W tym miejscu badania wykazały, że definicja reklamy gier cylindrycznych, gier w karty, gier w kości, zakładów wzajemnych lub gier na automatach wykracza poza obręb znanych definicji reklamy z uwagi na brak elementu podmiotowego.

${ }^{33}$ V. Konarska-Wrzosek, T. Oczkowski, J. Skorupka, Prawo i postępowanie karne skarbowe, Warszawa 2010, s. 330-331; M. Bik et al., Gry hazardowe. Komentarz do ustawy o grach hazardowych, Warszawa 2013, s. 99.

${ }^{34}$ V. Konarska-Wrzosek, T. Oczkowski, J. Skorupka, op. cit., s. 331. 
Zasadne wydaje się zatem zgłoszenie postulatu de lege ferenda o uzupełnienie tej definicji o elementy podmiotowe. Wobec tego definicja reklamy z art. 29 ust. 6 u.g.h. stanowiłaby, że: „przez reklamę gier cylindrycznych, gier w karty, gier w kości, zakładów wzajemnych lub gier na automatach rozumie się publiczne rozpowszechnianie znaków towarowych lub symboli graficznych i innych oznaczeń z nimi związanych, a także nazw i symboli graficznych podmiotów prowadzących działalność w zakresie gier cylindrycznych, gier w karty, gier w kości, zakładów wzajemnych lub gier na automatach oraz informacji o miejscach, w których takie gry lub zakłady są urządzane, i możliwościach uczestnictwa, służące popularyzowaniu znaków towarowych, symboli graficznych i innych oznaczeń z nimi związanych, a także służące popularyzowaniu nazw i symboli graficznych podmiotów prowadzacych działalność w tym zakresie”. Zaproponowana modyfikacja przepisu, pokazujaca reklamę jako zdarzenie celowościowe pozwoli na odróżnienie zachowania naruszającego zakaz od przypadkowych zachowań, często o czysto informacyjnym charakterze. Taka zmiana, zastosowana odpowiednio w zakresie rozumienia pojęcia reklamy, winna odnosić się także do art. 29 ust. 8 i 9 u.g.h.

W ocenie przedmiotowych rozważań z punktu widzenia precyzji użytych w definicjach sformułowań należy odnieść się do pojęcia reklamy z art. 29 ust. 6 u.g.h., a konkretnie zwrotu: „innych oznaczeń z nimi związanych”. „Związek” z grami lub zakładami wzajemnymi może wykazywać wiele nazw i symboli graficznych. Podobny problem jest przy definicji promocji (art. 29 ust. 7 u.g.h.), która mówi o rozdawaniu rekwizytów związanych z grami lub zakładami wzajemnymi, a zatem konieczne jest ustalenie, jaka rzecz ma związek z gra, czy zakładem wzajemnym, a jaka nie ma, co z oczywistych powodów może być bardzo trudne. Mimo uwag krytycznych w odniesieniu do tego nieostrego słowa, należy zaznaczyć, że funkcjonuje ono w definicjach reklamy na gruncie innych ustaw, m.in. ustawy o ochronie zdrowia przed następstwami używania tytoniu i wyrobów tytoniowych oraz ustawy o wychowaniu w trzeźwości i przeciwdziałaniu alkoholizmowi.

Podobne zastrzeżenia budzi nieostre słowo „podobieństwo” w art. 29 ust. 8 i 9 u.g.h. Stwierdzenie zaistnienia podobieństwa czegoś do oznaczeń gier cylindrycznych, gier w karty, gier w kości, zakładów wzajemnych lub gier na automatach, kasyna gry lub punktu przyjmowania zakładów wzajemnych może być na tyle trudne, że będzie wymagało opinii biegłego.

W końcu przy definicji informowania o sponsorowaniu, w której czytamy o ,prezentowaniu informacji”, brak słowa nadającego tej prezentacji powszechny, publiczny charakter. W pełni zasadna wydaje się zatem prosta modyfikacja zwrotu przez stwierdzenie, że przez informowanie o sponsorowaniu rozumie się „publiczne prezentowanie informacji”. Przy czym wcześniej powołana ustawa o wychowaniu w trzeźwości i przeciwdziałaniu alkoholizmowi wprowadza również definicję informowania o sponsorowaniu bez słowa nadającego prezentacji charakter publiczny.

Odpowiadając zatem na pytanie pomocnicze postawione we wstępie opracowania, należy stwierdzić, że użyte w analizowanych definicjach sformułowania nie są precyzyjne, ale poparte doktryną i orzecznictwem mogą funkcjonować. 
Ewentualnie jeżeli ustawodawca uzna za zasadną bardzo głęboką ingerencję w u.g.h., może na wzór ustawy - Prawo farmaceutyczne wprowadzić osobny rozdział definiujacy reklamę i promocję określonych gier hazardowych oraz informowanie o sponsorowaniu. Tu też korzystając z kształtujących się przecież cały czas poglądów nauki, należałoby precyzyjnie zdefiniować wszelkie nieostre pojęcia, w tym wprowadzić do definicji reklamy elementy podmiotowe.

W końcu odpowiadając na zasadnicze pytanie niniejszych rozważań, należy przyjąć, że brak elementów podmiotowych w definicji reklamy oraz udowodniona nieostrość kilku zwrotów występujących w badanych pojęciach moga rodzić pewne wątpliwości interpretacyjne, zarówno u teoretyków, jak i praktyków stosujących te przepisy.

dr hab. Grzegorz Skowronek

Profesor Wyższej Szkoty Informatyki i Zarzqdzania w Rzeszowie

gskowronek@wsiz.rzeszow.pl

\section{AN ANALYSIS OF THE NOTIONS: ‘ADVERTISING’ AND ‘PROMOTION’ OF GAMBLING}

\section{Sum mary}

This study is a thorough analysis of the notions 'advertising' and 'promotion' of gambling, as well as the notion 'information about sponsorship.' The key question which the author aims to answer is whether definitions of these concepts in the Polish gambling act are precise enough, or whether they should be replaced with other wording. In the course of the study the author notes that in the current definition of the advertising of gambling, the subjective elements are missing and certain formulations are vague. In view of these circumstances, the de lege ferenda postulate is to amend the existing definition. 
